\title{
EFFECTIVE SOIL STRENGTH PARAMETERS AND LOAD CAPACITY OF SHALLOW FOUNDATIONS ACCORDING TO VARIOUS POLISH DESIGN CODES
}

\begin{abstract}
Standard PN-EN-1997-1 (Eurocode 7 - introduced in 2010) requires the determination of bearing capacity of the subsoil on the basis of the effective values of geotechnical parameters. The total soil parameters can be used only to determine the bearing capacity in the so called "undrained conditions", in transitional situation (with a fast the increase of load and slow the outflow of water). The problem with correct qualification of effective parameter values is the obstacle to the widespread use of the new code. This especially concern a smaller structures, for which advanced researches of substrate is uneconomical. The paper presents the change in the approach to the design of shallow foundations and application for that purpose an effective values of the parameters in the Polish codes over time.
\end{abstract}

Keywords: polish norm, bearing capacity, drained conditions, effective values of geotechnical strength parameters

\section{Introduction}

The new norm PN-EN 1997-1 [1] was introduced in Poland in 2010. It changed the approach to designing shallow foundations. The changes included not only the calculation procedure, but above all a clear separation of the foundation's working conditions, and thus also its permissible load capacity. The separation of load-transfer situations to the "undrained" and "drained" conditions clearly indicated the need to determine the bearing capacity of ground based on the parameters, which were determined in similar research assumptions.

The approach was described as "innovative" in relation to the assumptions of the previous standard PN-81/B-03020 [4]. At this point, it should be reminded,

${ }^{1}$ Corresponding author: Krzysztof Wilk, Rzeszow University of Technology, Faculty of Civil and Environmental Engineering, Department of Geodesy and Geotechnics, address: ul. Poznanska 2, 35-959 Rzeszow, Poland, phone number:+48 1786510 06, e-mail: kwilk@prz.edu.pl. 
that the earlier obligatory codes drew attention to the dependence of a kind of used soil parameters from a loading conditions of the ground.

Using of effective parameters allow to design foundations more sparingly. Therefore it is a very rational approach, especially in terms of the economics investment. Besides this reduces the interference into the natural environment due to smaller foundation size.

Paradoxically, the requirement of using effective parameters is also an important issue in the widespread use of the new code [1]. It is associated with considerable costs, which the investor must bear in order to design them. those costs often exceed possible savings even for a medium-sized investment. It should be mentioned that the cost of a professionally made laboratory determination of soil parameters that is not only the cost of a single test. Depending on the complexity of the substrate, types of soils that build them, and also due to the need to ensure an adequate representativeness of the samples and to eliminate possible research errors more tests should be carried out properly. Taking samples of material with intact structure for the strength tests may be often problematic.

All listed circumstances make that costs of determining the effective parameters of soils, often significantly outweigh the value of the materials and earthworks which are the results of the foundation "oversizing".

\section{The strength parameters of soil determined in an indirect way}

It can not be disputed that carrying out on adequate research is the best way to determine the strength parameters. However, this procedure can generate costs which exceed the possible savings, in many simple cases of building foundations. The same standard Eurocode 7 [1] does not preclude designation of the soil quantity described in an indirect way. The determination of an appropriate correlation relating to the effective strength parameters is the main problem.

The dependencies which allow to indirectly determine soil's value strength parameters were included in the previous Polish standards. The adoption of their values is possible based on correlations with other (usually physical) parameters describing the ground. It should be noted that the indirect characterization of the substrate, even though by definition "less" accurate, was verified very well in practice. Any failures (connected with the direct foundation of buildings) were not caused by previously described methodology of determining mechanical properties of soil.

In case of non-cohesive soils, groundwater can relatively quickly drain from the samples during testing in triaxial apparatus. It is possible, because these soils have pore of large size. It is therefore concluded that effective parameters will be identical to the total values proposed in the previous codes [4]. 
As to cohesive soils, similar reasoning is not justified. So the relations given in PN-81/B-03020 [4] (Fig.1, Fig. 2) should not be used as referring the effective values of the parameters. What's more, other available literature does not contain enough practically confirmed knowledge, allowing to indirect determination of effective soil parameters.

Currently, most of the geotechnical documentation made for investments, classified as 1 and 2 geotechnical category, includes soil's strength parameters determined indirectly based on the correlations given in PN-81/B-03020 (Fig. 1, Fig. 2). Recommendation to determine a bearing capacity of foundations based on standard PN-EN 1997-1 [1] have been written in the same elaborations. These records are in clear contradiction.

However, it is common for engineers to use total parameters to determine the bearing capacity of subsoil. They are treated as effective values in calculations - even for soils with finer grain size.

Paradoxically, such approach usually leads to an overestimation of the necessary dimensions of shallow foundations. The calculated bearing capacity is then lower than in the application of the procedures given in the PN-81/B-03020 [4]. This situation negates the idea of usage the effective values of the soil parameters.

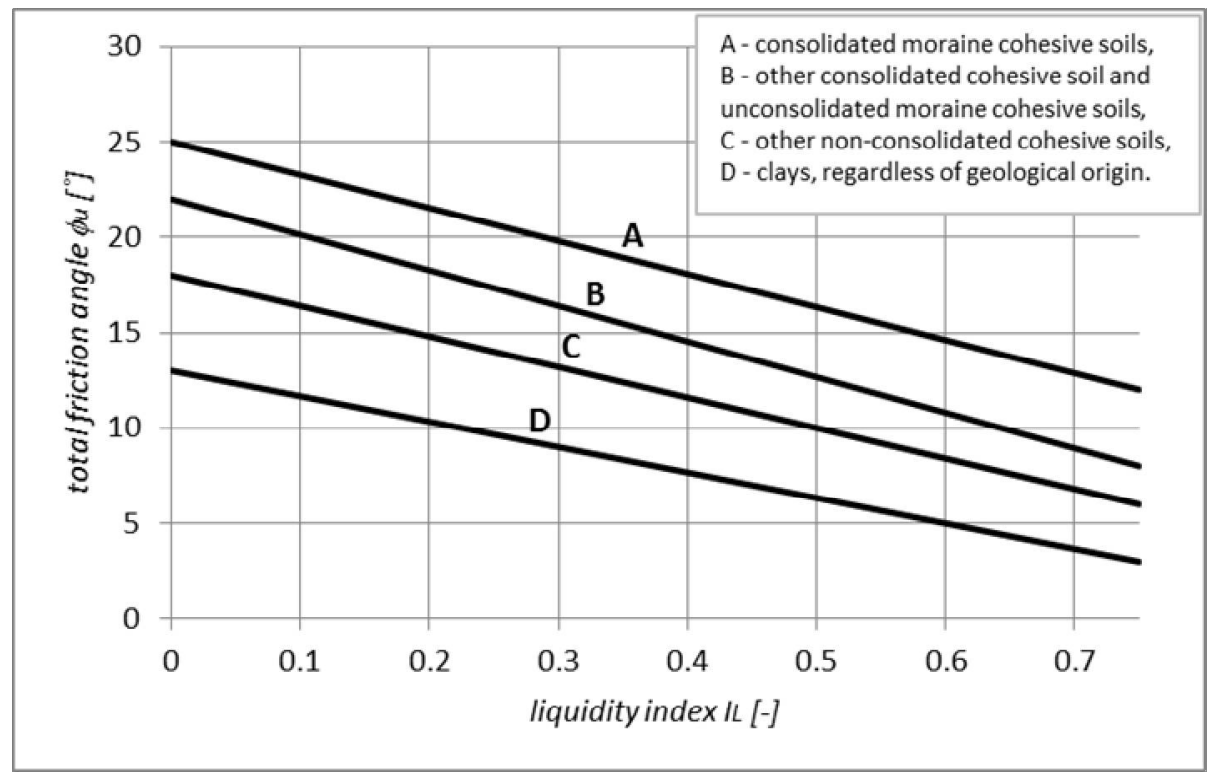

Fig. 1. Nomogram for depending the total value of the friction angle on the liquidity index according to $\mathrm{PN}-81 / \mathrm{B}-03020$ [4]

Rys. 1. Nomogram do określenia całkowitej wartości kąta tarcia wewnętrznego w zależności od stopnia plastyczności według PN-81/B-03020 [4] 


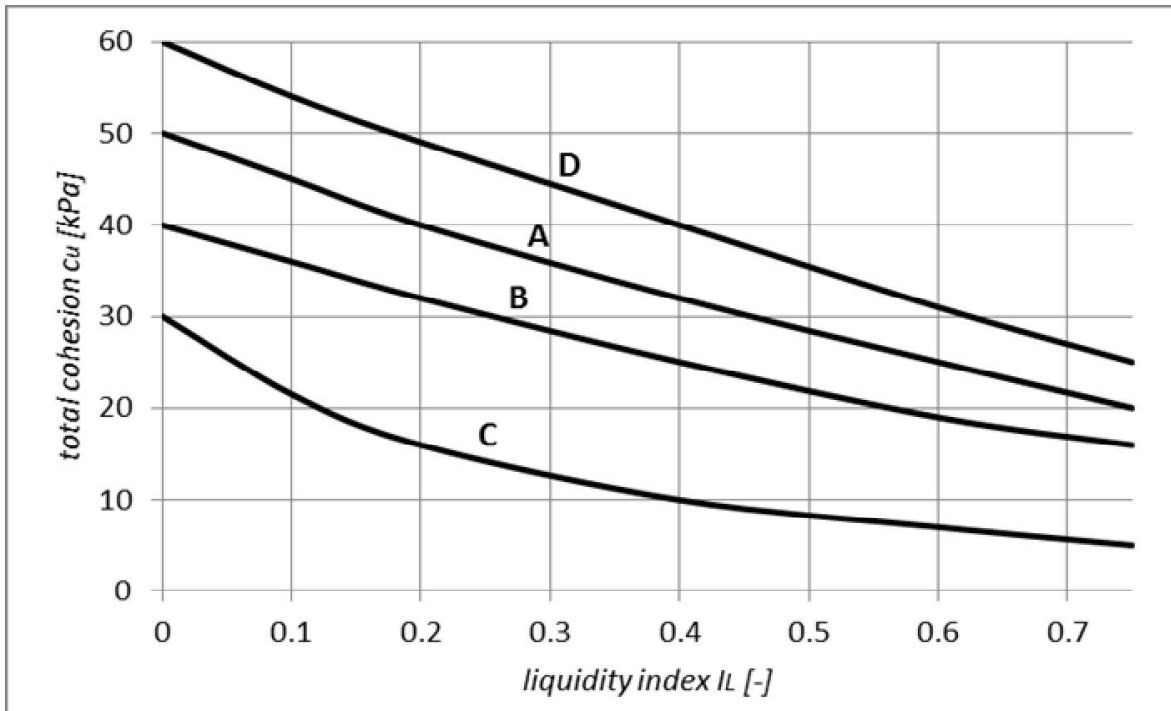

Fig. 2. Nomogram for depending the total value of the cohesion on the liquidity index according to $\mathrm{PN}-81 / \mathrm{B}-03020$ [4]

Rys. 2. Nomogram do określenia całkowitej wartości kohezji w zależności od stopnia plastyczności według PN-81/B-03020 [4]

\subsection{The parameters according to the standards before 2010 .}

"Return" to the standards from 1959 and 1974 can be one of the alternatives to the current "reality" of designing shallow foundation in cohesive ground. These codes, although forgotten now, indicated that to determine the bearing capacity of the ground strength parameter values adequate to ground load conditions should be used. They also proposed acceptable rules of their indirect selection.

The code PN-74/B-03020 [3] adopted variations of effective values only for friction angle of soil (Fig. 3), with unchanged cohesive values.

Polish norm PN-59/B-03020 presented a slightly different approach. There was acknowledged the values established for "slowly" loading as primary parameters of soil (Fig. 4, Fig. 5). Apart from them, the friction angle values relating to the "fast" loading were also placed. The characteristics of soil's strength was connected with the cohesion of the soil (as in the standards of 1981. and 1974.), not with the geological origins of ground.

Besides the effective strength parameters, Wiłun [6] also gives both parameters for "undrained" conditions. He suggests the use of cohesion value for the "undrained" conditions about $20 \%$ higher than for the "drained" conditions. Already, such subscriptions do not have in the book of the 2000 edition [7]. 


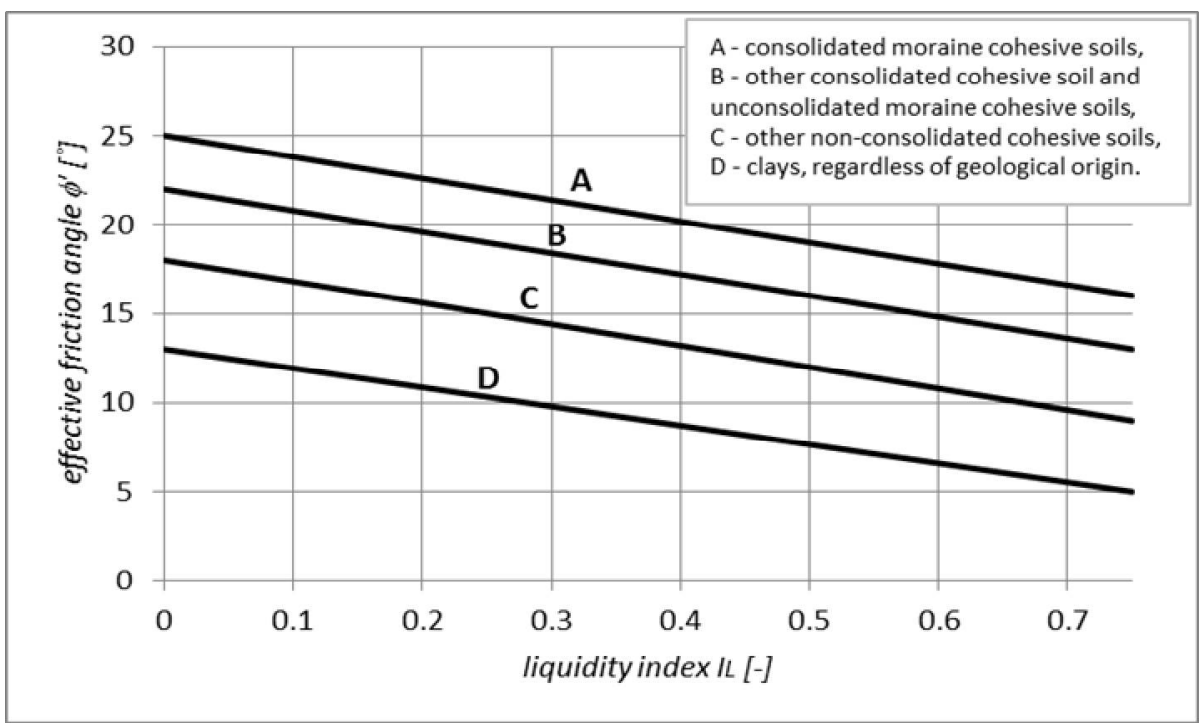

Fig. 3. Nomogram for depending the effective value of the friction angle on the liquidity index according to PN-74/B-03020 [3]

Rys. 3. Nomogram do określenia efektywnej wartości kąta tarcia wewnętrznego w zależności od stopnia plastyczności według PN-74/B-03020 [3]

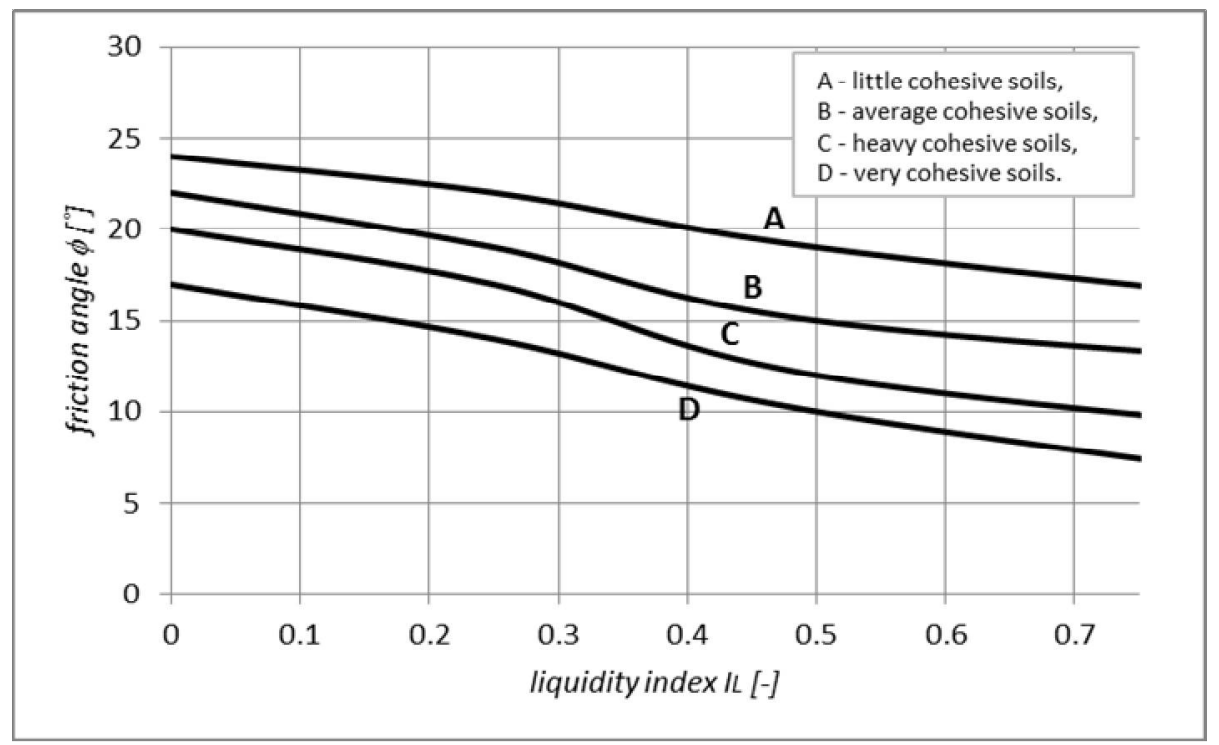

Fig. 4. Nomogram for depending the value of the friction angle (for "slowly" loading) on the liquidity index according to PN-59/B-03020 [2]

Rys. 4. Nomogram do określenia wartości kąta tarcia wewnętrznego (przy „powolnym” obciążeniu) w zależności od stopnia plastyczności według PN-59/B-03020 [2] 


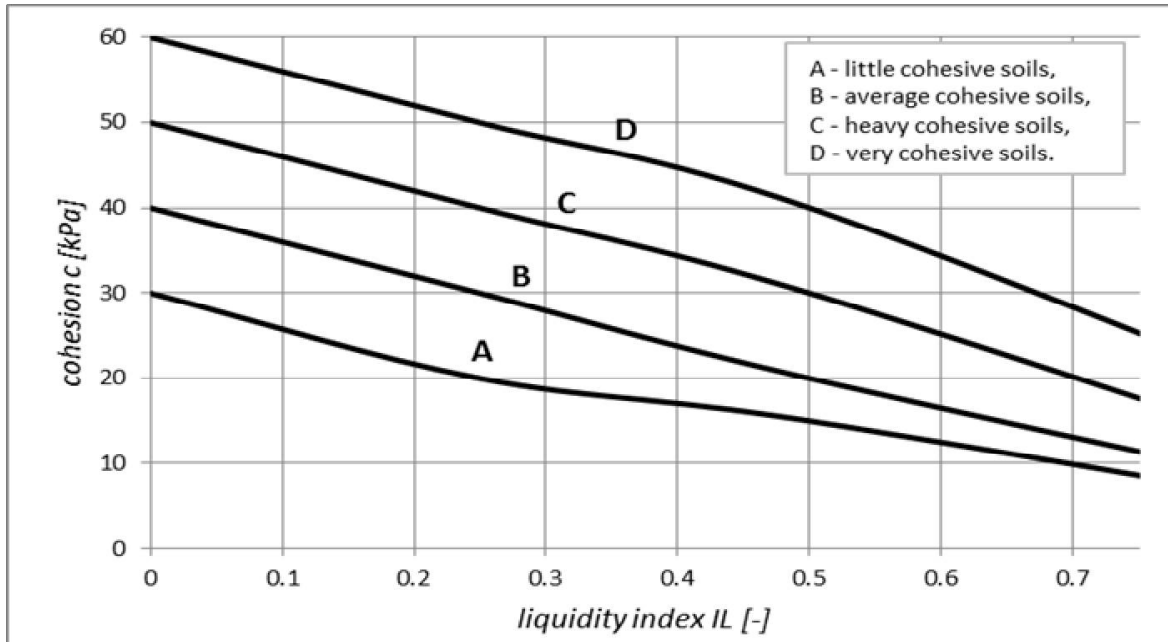

Fig. 5. Nomogram for depending the value of the cohesion (for "slowly" loading) on the liquidity index according to PN-59/B-03020 [2]

Rys. 5. Nomogram do określenia wartości kohezji (przy „powolnym” obciążeniu) w zależności od stopnia plastyczności według PN-59/B-03020 [2]

\subsection{The dependence of the parameters on pore water pressure}

The real value and the same the relationship (difference) between the total and effective values of strength parameters of cohesive soils is very difficult to determine. It will depend on the increase of water pressure in the pores of the soil material during the test in triaxial apparatus. Many factors will have influence on aforementioned the increase of water pressure. These will be: grainsize and permeability properties of the soil ground material, water content in soil pores, the degree of consolidation and the triaxial test parameters (in particular the value of sample's radial loading and velocity of the increase of axial force).

Multitude of these factors cause that determination of universal relationship between the values of effective strength parameters and other properties of the soil medium is very difficult.

The author has attempted to identify effective strength parameters in relation to the parameters and dependencies specified in PN-81/B-03020 [4] using the inverse analysis [5]. It was adopted that the increase of water pressure in soil pores during hypothetical triaxial tests is constant and proportional to the sample loading (Fig. 6, Fig. 7, Fig. 8, Fig. 9).

In connection with the friction angle, there was observed the increase of this value parameter with water pressure increase. In turn for cohesion, the significant decrease this value was observed for increasing participation of water pressure in soil pores [5]. 


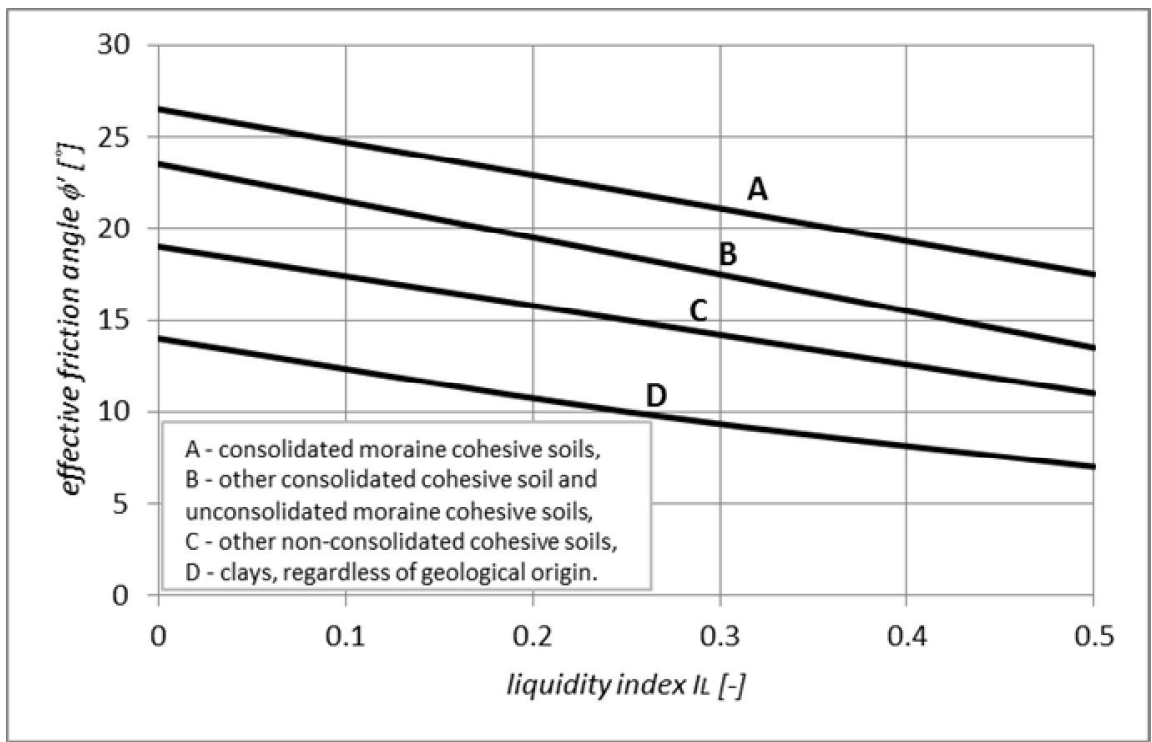

Fig. 6. Nomogram for depending the effective value of the friction angle on the liquidity index calculating for pore pressure $20 \%$

Rys. 6. Nomogram do określenia efektywnej wartości kąta tarcia wewnętrznego w zależności od stopnia plastyczności obliczane przy ciśnieniu w porach $20 \%$

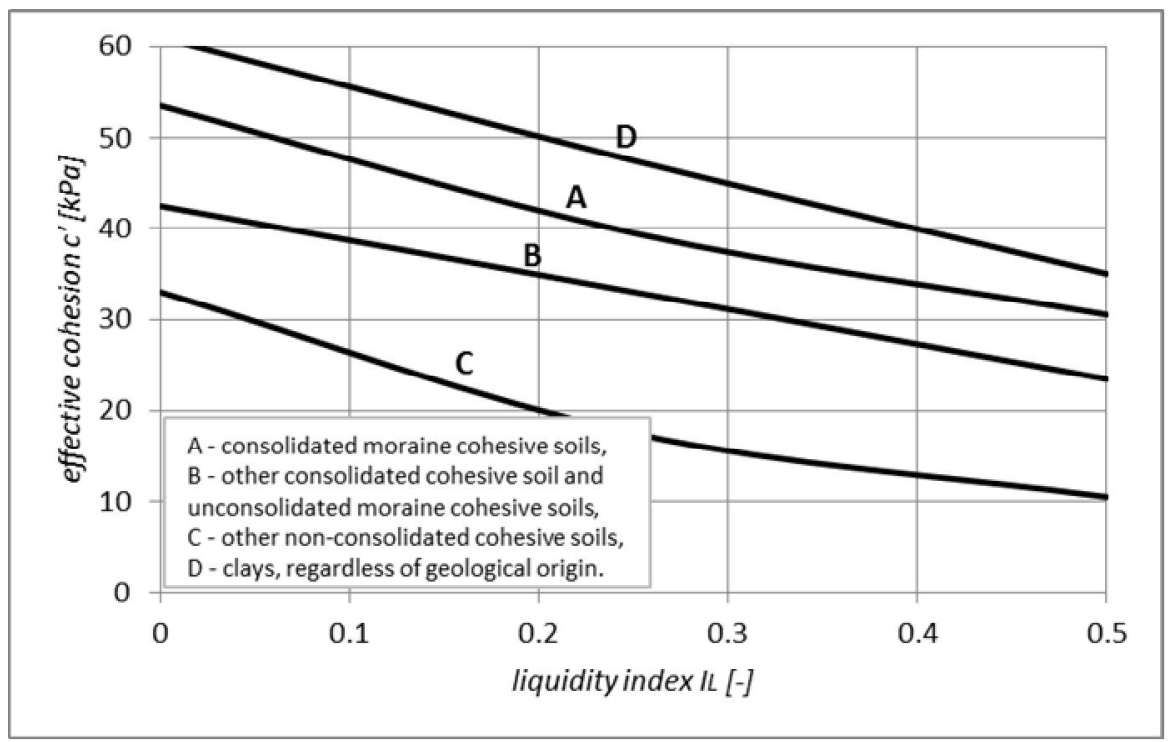

Fig. 7. Nomogram for depending the effective value of the cohesion on the liquidity index calculating for pore pressure $20 \%$

Rys. 7. Nomogram do określenia efektywnej wartości kohezji w zależności od stopnia plastyczności obliczane przy ciśnieniu w porach $20 \%$ 


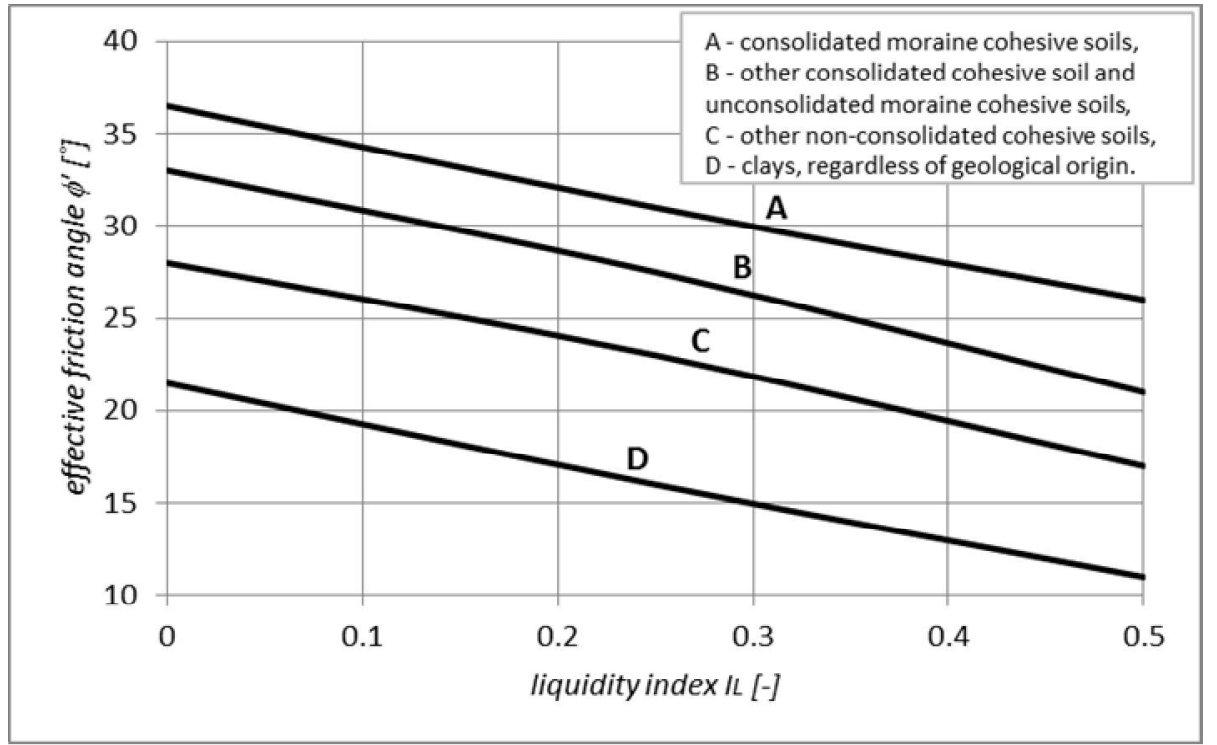

Fig. 8. Nomogram for depending the effective value of the friction angle on the liquidity index calculating for pore pressure $50 \%$

Rys. 8. Nomogram do określenia efektywnej wartości kąta tarcia wewnętrznego w zależności od stopnia plastyczności obliczane przy ciśnieniu w porach $50 \%$

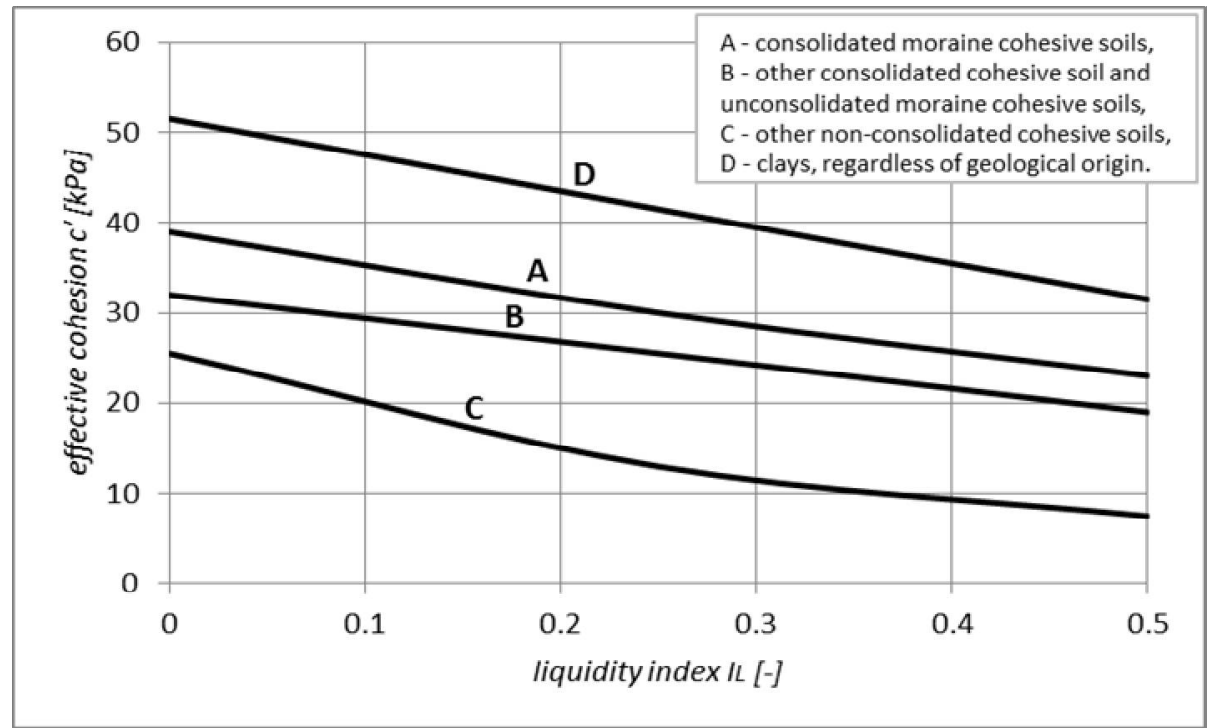

Fig. 9. Nomogram for depending the effective value of the cohesion on the liquidity index calculating for pore pressure $50 \%$

Rys. 9. Nomogram do określenia efektywnej wartości kohezji w zależności od stopnia plastyczności obliczane przy ciśnieniu w porach 50\% 


\section{Bearing capacity for different codes}

The calculation methods used in cited earlier standards will be presented shortly below. It is important for visualization and justification of the results of the analyzes presented later in this paper. Since 1974. shallow foundations have been designed based on the limit states method: ultimate limit state and serviceability limit state. Ultimate limit state should be checked with the appropriate partial factors that increase the safety factor of the structure.

The formula used to determine the bearing capacity by PN-EN 1997-1 [1] in "drained" conditions is describe as (1):

$$
R_{k}=B^{\prime *} L^{\prime *}\left[c^{\prime *} N_{c} * b_{c} * s_{c} * i_{c}+q^{\prime *} N_{q} * b_{q} * s_{q} * i_{q}+0,5 * \gamma^{\prime *} B^{\prime *} N_{\gamma} * b_{\gamma} * s_{\gamma} * i_{\gamma}\right]
$$

It will be simplified to the form (2) for situation with only vertical load on the foundation and for horizontally basis of foundation:

$$
R_{k}=B^{\prime *} L^{\prime *}\left[c^{\prime *} N_{c} * s_{c}+q^{\prime *} N_{q} * s_{q}+0,5 * \gamma^{\prime *} B^{\prime *} N_{\gamma} * s_{\gamma}\right]
$$

According to the previous standard PN-81/B-03020 [4], bearing capacity was determined by the following formula (3):

$$
\begin{aligned}
& Q_{f N B}=\bar{B} * \bar{L} *\left[\left(1+0,3 \frac{\bar{B}}{\bar{L}}\right) * c_{u}^{(r)} * N_{c} * i_{c}+\ldots\right] \\
& {\left[\ldots+\left(1+1,5 \frac{\bar{B}}{\bar{L}}\right) * \rho_{D}^{(r)} * g * D_{\min } * N_{D} * i_{D}+\left(1-0,25 \frac{\bar{B}}{\bar{L}}\right) * \rho_{B}^{(r)} * g * \bar{B} * N_{B} * i_{B}\right]}
\end{aligned}
$$

Previously used standard PN-74/B-03020 [3] gave the following form of formula to defined the bearing capacity of the substrate (4):

$$
Q_{f}=B * L *\left[\left(1+0,3 \frac{B}{L}\right) * c^{(r)} * N_{c}+\gamma_{D}^{(r)} * D_{\min } * N_{D}+\left(1-0,2 \frac{B}{L}\right) * \gamma_{B}^{(r)} * B * N_{B}\right]
$$

The code PN-59/B-03020 [2] used different computing approach to determine the bearing capacity - the method of allowable stresses. In this case yield strength was determined according to the equation (5):

$$
\sigma_{g r}=c * N_{c}+\frac{\gamma_{o}^{*} h_{f} * N_{h}}{10}+\frac{\gamma_{o}^{\prime} * b * N_{b}}{10}
$$


Based on the formula (5), the limit load value transferred by the substrate is (6):

$Q_{g r}=a * b *\left(c * N_{c}+\frac{\gamma_{o}^{*} h_{f} * N_{h}}{10}+\frac{\gamma_{o}^{\prime} * b * N_{b}}{10}\right)$

Notations used in the presented formulas $(1,2,3,4,5,6)$ are compatible with the standards which they concern.

\section{Analysis of bearing capacity with diverse methodology of calculation and way of selection of soil parameters}

Table 1. The characteristic of bearing capacity of the ground under the footing foundation, for $1 \times 1 \mathrm{~m}$ dimensions according to different standards $[\mathrm{kN}]$

Tabela 1. Charakterystyczna nośność gruntu pod stopą fundamentową o wymiarach 1x1 m według różnych norm $[\mathrm{kN}]$

\begin{tabular}{|c|c|c|c|c|c|}
\hline \multirow{8}{*}{ 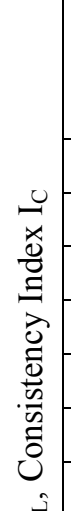 } & Symbol of soil & A & B & $\mathrm{C}$ & $\mathrm{D}$ \\
\hline & \multicolumn{5}{|c|}{$\mathrm{I}_{\mathrm{L}}=0,5, \mathrm{I}_{\mathrm{C}}=0,5$} \\
\hline & PN-EN 1997-1 ${ }^{*}$ [1] & 580,8 & 359,2 & 147,9 & 337,1 \\
\hline & PN-81/B-03020 [4] & 667,4 & 433,9 & 213,3 & 396,6 \\
\hline & PN-74/B-03020 [3] & 633,9 & 430,8 & 161,1 & 374,8 \\
\hline & PN-59/B-03020 [2] & 344,3 & 310,2 & 349,7 & 387,1 \\
\hline & \multicolumn{5}{|c|}{$\mathrm{I}_{\mathrm{L}}=0,25, \mathrm{I}_{\mathrm{C}}=0,75$} \\
\hline & PN-EN 1997-1*) [1] & 989,7 & 672,7 & 305,8 & 539,3 \\
\hline $\overrightarrow{0}$ & PN-81/B-03020 [4] & 1077,1 & 760,5 & 388,7 & 606,8 \\
\hline$\Xi$ & PN-74/B-03020 [3] & 979,6 & 679,2 & 302,3 & 551,6 \\
\hline 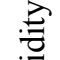 & PN-59/B-03020 [2] & 606,3 & 558,7 & 535,4 & 599,9 \\
\hline 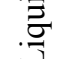 & \multicolumn{5}{|c|}{$\mathrm{I}_{\mathrm{L}}=0,0, \mathrm{I}_{\mathrm{C}}=1,0$} \\
\hline 0 & PN-EN 1997-1 ${ }^{*}[1]$ & 1885,6 & 1219,0 & 700,1 & 866,6 \\
\hline & PN-81/B-03020 [4] & 1930,6 & 1300,0 & 789,5 & 934,1 \\
\hline & PN-74/B-03020 [3] & 1614,1 & 1067,4 & 632,8 & 836,5 \\
\hline & PN-59/B-03020 [2] & 899,2 & 873,1 & 829,2 & 853,0 \\
\hline
\end{tabular}

${ }^{*}$ ) bearing capacity based on the total value of soil parameters adopted on the basis of the standard PN-81/B-03020 [4] 
The appropriate calculations were made to compare the effectiveness of different approaches to determine the bearing capacity under shallow foundations in a permanent "drained" situation. Their results were put together in the following tables. In each case, calculations were made for the same substrate conditions and load transfer, but other mechanical properties of the substrate. Calculations were executed for foundations situated at the depth of $1.0 \mathrm{~m}$, the width of $1.0 \mathrm{~m}$ and the length in two variants ie. $1.0 \mathrm{~m}$ (footing foundation) and $10.0 \mathrm{~m}$ (continuous footing). In each case the volume weight of soil was taken equal to $20 \mathrm{kN} / \mathrm{m}^{3}$. There was also assumed the easiest way to load ie. the action of vertical force only with gravity located in the center of the foundation base.

Table 2. The characteristic of bearing capacity of the ground under the continuous footing, for $1 \times 10 \mathrm{~m}$ dimensions according to different standards $[\mathrm{kN}]$

Tabela 2. Charakterystyczna nośność gruntu pod ławą fundamentową o wymiarach 1x10 m według różnych norm $[\mathrm{kN}]$

\begin{tabular}{|c|c|c|c|c|c|}
\hline \multirow{4}{*}{ 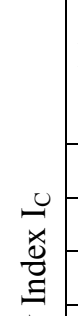 } & $\begin{array}{l}\text { Base } \\
\text { of calculation }\end{array}$ & A & B & $\mathrm{C}$ & $\mathrm{D}$ \\
\hline & \multicolumn{5}{|c|}{$\mathrm{I}_{\mathrm{L}}=0,5, \mathrm{I}_{\mathrm{C}}=0,5$} \\
\hline & PN-EN 1997-1* [1] & 4553,1 & 2893,5 & 1240,3 & 2805,6 \\
\hline & \begin{tabular}{|l|} 
PN-81/B-03020 [4] \\
\end{tabular} & 4592,4 & 2947,1 & 1294,0 & 2861,7 \\
\hline \multirow{4}{*}{ 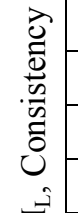 } & PN-74/B-03020 [3] & 5349,1 & 3643,2 & 1421,4 & 3057,9 \\
\hline & PN-59/B-03020 [2] & 3443,0 & 3101,7 & 3497,4 & 3871,2 \\
\hline & \multicolumn{5}{|c|}{$\mathrm{I}_{\mathrm{L}}=0,25, \mathrm{I}_{\mathrm{C}}=0,75$} \\
\hline & PN-EN 1997-1 ${ }^{*}[1]$ & 7547,6 & 5234,3 & 2467,2 & 4370,9 \\
\hline \multirow{8}{*}{ 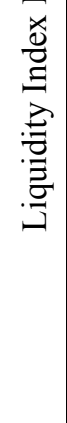 } & PN-81/B-03020 [4] & 7538,6 & 5265,2 & 2521,1 & 4428,2 \\
\hline & PN-74/B-03020 [3] & 8229,5 & 5707,9 & 2599,9 & 4486,3 \\
\hline & PN-59/B-03020 [2] & 6062,7 & 5587,4 & 5354,2 & 5998,9 \\
\hline & \multicolumn{5}{|c|}{$\mathrm{I}_{\mathrm{L}}=0,0, \mathrm{I}_{\mathrm{C}}=1,0$} \\
\hline & PN-EN 1997-1*) [1] & 13940,0 & 9200,7 & 5433,5 & 6844,3 \\
\hline & $\mathrm{PN}-81 / \mathrm{B}-03020$ [4] & 13782,3 & 9157,6 & 5460,6 & 6888,2 \\
\hline & PN-74/B-03020 [3] & 13465,8 & 8925,1 & 5303,9 & 6790,7 \\
\hline & PN-59/B-03020 [2] & 8992,0 & 8730,8 & 8292,3 & 8530,3 \\
\hline
\end{tabular}

${ }^{*}$ bearing capacity based on the total value of soil parameters adopted on the basis of the standard PN-81/B-03020 [4]

Simulations were carried out without partial safety factors. Their values can lead to misinterpretation because they are different for the different 
computational approaches. Their importance may be decisive depending on the specific normative recommendations, as well as the analysis of different load cases in different soil conditions. However, their primary task is to increase building safety. They do not influence the "real" bearing capacity of the ground.

\subsection{Bearing capacity according to different codes}

Characteristic values of bearing capacity were compared because the rules for determining the safety margin in particular codes are different.

Table 3. The characteristic of bearing capacity of the ground under the footing, for $1 \mathrm{x} 1 \mathrm{~m}$ dimensions, calculated according to PN-EN 1997-1 [1] for, with the assumption of different values of the soil parameters $[\mathrm{kN}]$

Tabela 3. Charakterystyczna nośność gruntu pod stopą fundamentową o wymiarach $1 \mathrm{x} 1 \mathrm{~m}$, obliczana według PN-EN 1997-1 [1] z uwzględnieniem różnych wartości parametrów gruntu [kN]

\begin{tabular}{|c|c|c|c|c|c|}
\hline & $\begin{array}{l}\text { Symbol of soil } \\
\text { Basis of } \\
\text { parameters selection }\end{array}$ & A & B & $\mathrm{C}$ & $\mathrm{D}$ \\
\hline \multirow{5}{*}{ 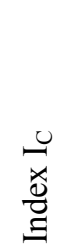 } & \multicolumn{5}{|c|}{$\mathrm{I}_{\mathrm{L}}=0,5, \mathrm{I}_{\mathrm{C}}=0,5$} \\
\hline & PN-81/B-03020 [4] & 580,8 & 359,2 & 147,9 & 337,1 \\
\hline & $\left.\bmod .(\mathrm{u}=20 \% \sigma)^{* *}\right)$ & 681,4 & 407,7 & 189,5 & 359,5 \\
\hline & mod. $\left.(\mathrm{u}=50 \% \sigma)^{* *}\right)$ & 1172,0 & 650,6 & 266,3 & 430,1 \\
\hline & PN-74/B-03020 [3] & 710,8 & 471,5 & 175,3 & 371,4 \\
\hline 过 & PN-59/B-03020 [2] & 443,5 & 405,9 & 468,1 & 492,8 \\
\hline$\cdot \frac{n}{n}$ & \multicolumn{5}{|c|}{$\mathrm{I}_{\mathrm{L}}=0,25, \mathrm{I}_{\mathrm{C}}=0,75$} \\
\hline \multirow{11}{*}{ 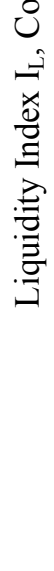 } & PN-81/B-03020 [4] & 989,7 & 672,7 & 305,8 & 539,3 \\
\hline & mod. $\left.(\mathrm{u}=20 \% \sigma)^{* *}\right)$ & 1206,9 & 785,2 & 369,0 & 573,6 \\
\hline & $\left.\bmod .(\mathrm{u}=50 \% \sigma)^{* *}\right)$ & 2300,9 & 1450,6 & 624,7 & 779,6 \\
\hline & PN-74/B-03020 [3] & 1122,4 & 759,3 & 332,0 & 557,5 \\
\hline & PN-59/B-03020 [2] & 815,6 & 759,3 & 736,3 & 790,5 \\
\hline & \multicolumn{5}{|c|}{$\mathrm{I}_{\mathrm{L}}=0,0, \mathrm{I}_{\mathrm{C}}=1,0$} \\
\hline & PN-81/B-03020 [4] & 1885,6 & 1219,0 & 700,1 & 866,6 \\
\hline & $\left.\bmod .(\mathrm{u}=20 \% \sigma)^{* *}\right)$ & 2275,5 & 1453,5 & 817,5 & 942,9 \\
\hline & $\left.\bmod .(\mathrm{u}=50 \% \sigma)^{* *}\right)$ & 5019,7 & 2970,9 & 1524,1 & 1436,4 \\
\hline & PN-74/B-03020 [3] & 1885,6 & 1219,0 & 700,1 & 866,6 \\
\hline & PN-59/B-03020 [2] & 1241,7 & 1219,0 & 1166,7 & 1153,6 \\
\hline
\end{tabular}

**) effective parameters defined using retrospective analysis, based on the total values of soil parameters from PN-81/B-03020 [4], assuming a pore water pressure at the level of $20 \%$ or $50 \%$ stress loading the soil sample tested in the triaxial apparatus 
The calculations were carried out for soil parameters in a permanent design situation ("drained" conditions), which are suggested for use by each standard, except the standard Eurocode 7 [1]. Unfortunately, such correlations do not contain actually norm PN-EN 1997-1 [1]. However, previous standard PN-81/B-03020 [4] requires conducting these calculations based on the total parameters values.

Table 4. The characteristic of bearing capacity of the ground under the continuous footing, for 1x10 m dimensions, calculated according to PN-EN 1997-1 [1] for, with the assumption of different values of the soil parameters $[\mathrm{kN}]$

Tabela 4. Charakterystyczna nośność gruntu pod ławą fundamentową o wymiarach 1x10 m, obliczana według PN-EN 1997-1 [1] z uwzględnieniem różnych wartości parametrów gruntu [kN]

\begin{tabular}{|c|c|c|c|c|c|}
\hline & \multicolumn{1}{|c|}{$\begin{array}{l}\text { Symbol of soil } \\
\text { of parameters } \\
\text { selection }\end{array}$} & $\mathrm{A}$ & $\mathrm{B}$ & $\mathrm{C}$ & $\mathrm{D}$ \\
\hline \multicolumn{5}{|c|}{$\mathrm{I}_{\mathrm{L}}=0,5, \mathrm{I}_{\mathrm{C}}=0,5$} \\
\hline
\end{tabular}

**) effective parameters defined using retrospective analysis, based on the total values of soil parameters from PN-81/B-03020 [4], assuming a pore water pressure at the level of $20 \%$ or $50 \%$ stress loading the soil sample tested in the triaxial apparatus 


\subsection{Bearing capacity according to the values of soil parameters}

Currently bearing capacity of the subsoil should be determined based on the PN-EN 1997-1 [1]. The issue that remains unsolved today is the possibility of indirect selection of soil parameters. It is permitted by the new standard [1] in case of investments classified as 1 or 2 geotechnical category. Clear recommendations for effective strength parameters correlation with the physical soil properties are deficient. The results of the analysis for determining a bearing capacity according to PN-EN 1997-1 [1] were presented in tables 3. and 4. The effective values of parameters were selected according to the formula contained in previously used sources. In addition, an effective parameters were determined by the retrospective analysis and were used in comparisons. Their values were assigned based on the output of total parameters adopted on the basis of the PN-81/B-03020 [4]. The increase of pore water pressure was established at $20 \%$ and $50 \%$ level of stress loading sample during the hypothetical triaxial tests.

\section{Conclusions}

The results overview presented in Tables 1., 2., 3. and 4., proves that we should definitely reject the possibility of using for bearing capacity calculations soil strength parameters suggested by the norm PN-59/B-03020 [2]. This disqualification is essential, even taking into account the fact that only for soils from group D this standard can be compared with similar soils described in standards PN-74/B-03020 [3] and PN-81/B-03020 [4]. Other types of substrate, described as symbols $\mathrm{A}, \mathrm{B}$ and $\mathrm{C}$ are incompatible with one another, due to different partition criteria. It should be noted that different soils specified in PN-59/B-03020 [2] have similar bearing capacity at the same liquidity index. The lower liquidity index cause the smaller differences (from $11 \%$ maximum when $\mathrm{I}_{\mathrm{L}}=0.5$ to $4 \%$ maximum with $\mathrm{I}_{\mathrm{L}}=0,0$ ). This is the basis for skeptical approach to reliable values of the parameters contained there.

It can be seen, by comparing other norms, that in case of footings the greatest bearing capacity were obtained for standard PN-81/B-03020 [4]. The code PN-74/B-03020 [3] is the most favorable in case of continuous footings and for smaller values of the liquidity index. It should be noted at this point that the norm PN-74/B-03020 [3] proposes the highest values of soil parameters.

Very similar results were gotten for continuous footings determining the bearing capacity according to PN-EN 1997-1 [1] and PN-81/B-03020 [4]. The variances are much larger for footing foundations. Stronger substrate mainly increases calculated bearing capacity based on the method Eurocode 7 [1]. It is for both types of shallow foundations. 
Rejecting of excessively large parameters established for pore water pressure on $50 \%$ level of stress influencing on the sample seem to be reasonable. The average increase of bearing capacity is then almost double than for unchanged values of the parameters adopted on the basis of PN-81/B-03020 [4].

The bearing capacity calculated for effective parameters of soil should not be worse than the specified reliable standard PN-81/B-03020 [4]. Choosing parameters based on the PN-74/B-03020 [3] adapt to Eurocode 7 [1] procedure seem rational. This standard was recommended to increase the friction angle with unchanged cohesion value. In most cases such approach will cause some bearing capacity underestimation of the of footing foundations and bearing capacity revaluation of continuous footing in relation to the norm PN-81/B03020 [4].

One of the alternatives could be the possibility of using modified strength parameters set for "unexaggerated" values of pressure of water contained in the soil pores (ie. $u=20 \%$ ). In this case the strong soils gain most.

Finding a system and at the same securing a way to selecting effective soil parameters is very necessary. The usage of total parameters in their place (as it is commonly practiced, based on the PN-81/B-03020 [4]) is hardly rational. This causes unnecessary foundation "oversizing". The widespread values determination of effective strength parameters as results of laboratory tests is unlikely. Such approach will be always too expensive for smaller investments. Thus a consensus is required to establish such parameters indirectly. This article, and above all analysis contained in it are an attempt to induce such discussion. The described issue is still valid despite the fact that five years has gone since standard Eurocode 7 [1] were introduced in Poland.

\section{Bibliography}

[1] Polish Norm PN-EN 1997-1:2010 Eurocode 7. Geotechnical design. Part 1: General rules.

[2] Polish Norm PN-59/B-03020 Building soils. The guidelines for determining a permissible intensity loads.

[3] Polish Norm PN-74/B-03020 Building soils. Foundation bases design and static calculation.

[4] Polish Norm PN-81/B-03020 Building soils. Foundation bases. Static calculation and design.

[5] Wilk K.: The meaning of effective soil parameters for determining of the bearing capacity of cohesive soils. Civil Engineering and Architecture, vol. 13 (2), Lublin University of Technology Faculty of Civil Engineering and Architecture, Lublin 2014, pp. 57-64,

[6] Wiłun Z.: Geotechnical outline. Publishing of Transports and Communications, Warsaw 1976. 
[7] Wiłun Z.: Geotechnical outline. Publishing of Transports and Communications, Warsaw 2000.

\section{EFEKTYWNE PARAMETRY WYTRZYMALOŚCIOWE GRUNTU I NOŚNOŚĆ FUNDAMENTÓW BEZPOŚREDNICH WEDLUG RÓŻNYCH POLSKICH NORM PROJEKTOWYCH}

Norma PN-EN-1997-1 (Eurocode 7 - wydana w 2010r) wymaga określenia nośności gruntu na podstawie efektywnych wartości parametrów geotechnicznych. Całkowite parametry gruntu mogą być używane tylko po to aby określać nośność gruntu z tak zwanych "warunków nieosuszonych", w sytuacji przejściowej (z szybkim przyrostem obciążenia i wolnym wypływem wody). Problem $\mathrm{z}$ odpowiednimi określeniem realnych wartości parametrów gruntu jest przeszkodą w szerszym użyciu nowych norm. Niepokój budzą zwłaszcza niewielkie obiekty, dla który zaawansowane badania podłoża gruntowego nie są ekonomiczne. Artykuł przedstawia zmianę podejścia do projektowania płytkich fundamentów i określania w tym celu realnych wartości parametrów gruntowych w polskich normach na przestrzeni lat.

Słowa kluczowe: polskie normy, nośność, warunki osuszania, efektywne wartości geotechnicznych parametrów wytrzymałościowych

Przestano do redakcji:26.05.2015

Przyjęto do druku:1.12.2015

DOI: $10.7862 / \mathrm{rb} .2015 .168$ 